\title{
水之生命 (抄録)
}

\section{大阪大学名誉教授 \\ 赤堀 四郎}

この地球上の生物は水が無ければ生きられない。それ は多分原始の地球上で，最初の生物が海の中で生れたか らであろらといわれている. 生体内の無機イオンの種類 や濃度が，海水のそれに近いこともそれを襄づけてい る. 地球上に本圏が生ずる前比生成していた種々の生体 成分一アミ，酸，脂肪酸，核酸湓基等が水圏に流し出さ れて生じた，いわゆる鬼のスープの中で最初の生命は或 いは偶然に生れたとしか考えられない，その原始生命は 恐らく海水中に浮遊した状態で生れたものであるう。こ らして, 生命活動はその発端から水とは縁の切れないる のであつたと思われる。

水は $\mathrm{H}_{2} \mathrm{O}$ の組成を有しその分子重は18であるが，液体 の水は複数個の $\mathrm{H}_{2} \mathrm{O}$ が環境に応じて水素結合によつて種 々の会合分子を形成している，それによつて水は他の低 分子物質とは著しく異なつた液体の水るつくつている。 その一例として氷と共に分子量が氷に近い物質 3 種，す なわらメタン，フンモニア和よび弗化水素の沸点叔よび 融点を示すと次表の通りである.

\begin{tabular}{lcrr} 
分子物 & 分式 & \multicolumn{1}{c}{ 沸点 } & \multicolumn{1}{c}{ 融 点 } \\
メタン & 16 & $-161.4^{\circ}$ & $-182.6^{\circ}$ \\
アンモ & 17 & $-33.35^{\circ}$ & $-77.7^{\circ}$ \\
水 & 18 & $+100^{\circ}$ & $0^{\circ}$ \\
弗化水素 & 19.5 & $+19.5^{\circ}$ & $-83.5^{\circ}$
\end{tabular}

また多くの人が知つているように，水が氷になるとき には容積が著しく膨張する.このことは水の警くべき特 徵である.水の比重は十 4 ○で最高になり，00で氷にな るまで徐々に減少する，それ故池の水が凍結するときは 表面から凍る。幸にも承㤬熱の不導体であるから，池は 深部まで涷ることから免かれる，魚類にとつて何といら 幸なことであるう。

その他，水の分子はその水素結合をつくり易いことに 基づき，その存在状態に応じて著しく多様な举動をと り，生命にとつて不可欠な種々の物理的性質を示するの である．生命との関係は末だ不明であるが，関 集三博 土は水もガラス状態になり得るという極めて注目すべき 発見を報告している。

無機イオンの示寸種々の生理的意義等も，蛋白質の本 和の問題と共に, 今後さらに澡く研究されるべき課題で あると信ずる。それの問題を思いつくままに述べてみた い. 